\title{
Performance and Egg Quality of Japanese Quails Submitted to Cyclic Heat Stress
}

\section{-Author(s)}

Vercese $F^{1}$

Garcia EA ${ }^{2}$

Sartori $\mathrm{JR}^{3}$

Silva A de $P^{1}$

Faitarone $A B G$

Berto DA ${ }^{1}$

Molino A de B

Pelícia $\mathrm{K}^{4}$

1 Students of the Post-Graduation Program in Animal Science, FMVZ/UNESP. Botucatu, $\mathrm{SP}$, Brazil.

2 Head Prof. of the Dept. of Animal Production, FMVZ/UNESP. Botucatu, SP, Brazil.

3 Ph.D., Assist. Prof. of the Dept. of Genetic Improvement and Animal Nutrition, FMVZ/ UNESP. Botucatu, SP, Brazil.

4 Prof. of the Dept. of Animal Science, UNIFENAS. Alfenas, MG, Brazil.

\section{-Mail Adress}

\section{Francine Vercese}

Depto. de Melhoramento e Nutrição Animal

FMVZ/UNESP - Campus de Botucatu

Caixa Postal 560

Rua Rubião Júnior, s/n

18.618-000. Botucatu, SP, Brasil.

E-mail: francinevercese@yahoo.com.br

\section{-Keywords}

Coturnix coturnix japonica, egg production, environmental temperature, heat stress, postpeak egg production.

\begin{abstract}
Aiming at evaluating the influence of cyclic temperatures on the performance and egg quality of Japanese quails an experiment was carried out with 480 birds after egg production peak. Birds were housed in a bioclimatic chamber with automatic temperature control that contained two rooms, one maintained at thermoneutral temperature $\left(21^{\circ} \mathrm{C}\right)$ and the other adjusted for the tested cyclic temperatures $(24$, $27,30,33$ and $36^{\circ} \mathrm{C}$ at a time). Each room had a battery of five floors and ten cages, with a capacity of 24 birds per cage, totaling 240 birds per battery. Birds were fed iso-nutritious and iso-caloric diets. Data obtained under the tested cyclic temperatures were compared with those obtained under thermoneutral temperature. At the end of each experimental period ( 14 days) performance and egg quality parameters were evaluated. A completely randomized experimental design with two treatments (thermoneutral temperature and tested temperature) and ten replicates of 24 birds each. Cyclic increases of $27^{\circ} \mathrm{C}$ and higher in environmental temperature negatively affected bird performance, with reduced feed intake and consequent reductions in egg weight and mass. A cyclic increase of the environmental temperature to $36^{\circ} \mathrm{C}$ reduced the percentage of saleable eggs and egg production.
\end{abstract}

\section{INTRODUCTION}

The increasing productivity and development of the poultry production brought about by advances in genetics, management, nutrition, health, and facilities allows reducing production costs and improving the quality of the final product. The domestic and international markets demand today excellent product quality, and are increasingly concerned with animal welfare and food safety, as well as with the management practices adopted by the poultry meat and egg production chain (Mazzuco, 2006).

As well as meat-type poultry production, Brazilian chicken egg exports have entered new markets, especially for the Arab countries, and this may also be an opportunity for Brazilian quail eggs.

According to Tinôco (1995), thermal factors, including air temperature, humidity, heat radiation, and air movement are the environmental factors that have the most direct influence on bird comfort, as they affect the maintenance of body temperature. The achievement of the best economic and productive results in modern poultry production requires taking into consideration not only genetics, nutrition and health, but also environmental factors (Baêta, 1998).

Environmental thermal comfort was considered a secondary issue for a long time, both from animal behavior and performance perspectives. It was assumed that thermal discomfort could be solved by the use of air conditioning, and no consideration was given to the costs and 
problems related to the implementation of an airconditioning system. However, as mentioned by Silva (1999), there has been an increasing concern with the thermal comfort of animals during the last decade, particularly with aspects related to physiological and performance responses.

As all homeothermal animals, birds present constant internal body temperature. According to thermodynamic principles, this means that these animals continuously exchange heat with the environment, but this process is efficient only if the environmental temperature is within the thermoneutral range (Hannas, 1999).

When environmental temperatures are above that range, bird rectal temperature increases, as well as its respiratory rate, that is, panting is used by birds to promote heat evaporative loss, thereby trying to maintain body temperature (Silva et al., 2001; Macari et al., 2004). Bottje \& Harrison (1985) and Furlan et al. (1999) also associated the increase in respiratory rate to reduce body temperature by evaporation under heat-stress situations. At the same time, physiological processes are activated to increase heat dissipation and to reduce metabolic heat production (Yahav et al., 2005). Under heat stress, chicken respiratory rate may increase from 29 cycles per minute to over 100 cycles per minute, resulting in an increase in carbon dioxide loss from the lungs, which leads to lower partial blood pressure of carbon dioxide, and therefore, reduced bicarbonate blood levels, increasing blood $\mathrm{pH}$, a condition called alkalosis. This limits the availability of anions required for the formation of calcium carbonate crystals of the eggshell (Mongin, 1968), and consequently, poor egg quality. According to Campos (2000), this may result in $12 \%$ reduction in eggshell thickness.

Therefore, environmental temperature and humidity are important for egg production. Birds managed outside thermoneutral ranges may suffer severe physiological changes, including reduced feed intake, and consequent low egg production and poor egg quality, including light eggs, low yolk percentage and weight, and low specific gravity (Macari et al., 1994; Nääs, 1992). Taking these facts into consideration, this study aimed at evaluating the effects of cyclic temperatures on the performance and egg quality of Japanese quails housed in a bioclimatic chamber.

\section{MATERIALS AND METHODS}

After the peak of egg production (36 weeks of age), 480 Japanese quails (Coturnix coturnix japonica) were housed in a climatic chamber with automatic temperature control containing two rooms $(4.30 \mathrm{~m}$ long $\times 4.5 \mathrm{~m}$ wide $\times 2.60 \mathrm{~m}$ high, each). Each room was equipped with a battery with five floors with two cages made of galvanized iron per floor. Cages were $100 \mathrm{~cm}$ long $\times 34 \mathrm{~cm}$ deep $\times 16 \mathrm{~cm}$ high and were divided into six internal compartments each with the capacity of housing four birds; therefore, 24 birds were housed per cage at a density of $141.67 \mathrm{~cm}^{2} /$ birds.

One of the rooms was kept at thermoneutral temperature (21 a $23^{\circ} \mathrm{C}$ ), whereas in the other room, birds were submitted to cyclic heat stress at five different temperatures $\left(24,27,30,33\right.$ or $\left.36^{\circ} \mathrm{C}\right)$ per experimental period. Cyclic heat stress consisted of exposing the birds daily for 14 days to 12 hours at the tested temperature $\left(24,27,30,33\right.$ or $\left.36^{\circ} \mathrm{C}\right)$ from 07:00 to 19:00, after which the temperature was set to $21-23^{\circ} \mathrm{C}$ for the next 12 hours.

All birds were submitted to the same feeding management, being fed twice daily an iso-nutritious and iso-caloric diet based on corn and soybean meal, containing 2,800 kcal ME/kg feed, $20 \%$ crude protein, $3.2 \%$ calcium, $0.35 \%$ available phosphorus, $0.45 \%$ methionine, $0.76 \%$ methionine + cystine, and $1.07 \%$ lysine. Feed and water were available ad libitum. A lighting program of $17 \mathrm{~h}$ of light was adopted.

At the end of the experimental period (14 days), performance and egg quality data collected from birds maintained under thermoneutral temperature (daily temperatures of 21 to $23{ }^{\circ} \mathrm{C}$ ) to those obtained from birds housed under cyclic temperature. A completely randomized experimental design was adopted, with two treatments (thermoneutral temperature and cyclic temperature) of ten replicates of 24 birds each.

Feed intake and egg weight were measured, and egg production percentage, saleable egg percentage, and feed conversion ratio ( $\mathrm{kg}$ feed per dozen eggs and per kg eggs) were calculated.

Egg quality was evaluated by collecting a sample of two eggs per experimental unit for three consecutive days. Eggs were individually identified, and weight in a high-precision scale, totaling 60 eggs per temperature tested.

Egg specific gravity was determined using saline solutions with densities ranging between 1.060 and 1.100 at 0.005 intervals. Yolk, albumen, and eggshell were weighed and their percentages were calculated dividing their respective weights by egg weight, and multiplying the result by 100 . Yolk index was calculated dividing yolk height by yolk diameter, measured 
with a digital caliper. In order to determine eggshell thickness, eggshells were dried in an oven at $60^{\circ} \mathrm{C}$ for three days, and their thickness was determined as the average thickness measured in three different points at the middle area zone using a digital caliper ruler.

Eggshell breaking strength was determined at the egg equatorial region using a texture analyzer (TA.XT Plus - Texture Analyser), with a 2-mm breaking probe, pre-test speed of $2 \mathrm{~mm} / \mathrm{s}$, test speed of $1.0 \mathrm{~mm} / \mathrm{s}$ and post-test speed of $40 \mathrm{~mm} / \mathrm{s}$. The result is expressed in grams.

In order to calculate of Haugh units, albumen height was first determined using a digital caliper, which then was applied to the following equation, as described by Brant et al. (1951): $\mathrm{HU}=100 \log \left(\mathrm{H}+7.57-1.7 \mathrm{~W}^{0.37}\right)$, where $\mathrm{H}=$ albumen height $(\mathrm{mm}) ; \mathrm{W}=$ egg weight (g); 7.57= correction factor for albumen height; $1.7=$ correction factor for egg weight.

Performance and egg quality data were analyzed according to a completely randomized experimental design with two treatments (thermoneutral temperature and cyclic temperatures) and ten replicates of 24 birds each. Data were submitted to analysis of variance with the aid of SAS statistical package (2000). Means were compared by the test of Tukey at $5 \%$ significance level.

\section{RESULTS AND DISCUSSION}

The performance results of Japanese quails in the phase of after egg production peak submitted to cyclic heat stress are presented in Table 1.

Table 1 shows that there were no significant effects of treatments on none of the evaluated parameters when comparing 21 to $24^{\circ} \mathrm{C}$. These results allow us to assert that, despite being outside the optimal temperature range for laying, which according to Murakami \& Ariki (1998) is between 18 and $22{ }^{\circ} \mathrm{C}$, quails presented good performance.

When the control temperature was compared to $27^{\circ} \mathrm{C}$ cyclic temperature, feed intake was reduced in $7.8 \%$, which negatively by the test of Tukey $(p \leq 0.05)$. influenced other performance parameters, such as egg weight, egg mass and feed conversion ratio per dozen. When feed intake obtained at thermoneutral temperature $\left(21^{\circ} \mathrm{C}\right)$ was compared those verified at cyclic temperatures of 30,33 and $36^{\circ} \mathrm{C}$, there was a significant reduction in $11.97 ; 16.67$ and $21.55 \%$, respectively. This may be explained by the difficulty birds have to dissipate internal heat when environmental temperature is high (Yunis \& Cahaner, 1999).

Egg production significantly dropped, in $6.67 \%$, only when birds were submitted to cyclic heat stress of $36^{\circ} \mathrm{C}$. This is consistent with the findings of Jones et al. (1976), who submitted White Leghorn layers to $24.5^{\circ} \mathrm{C}$ and $35^{\circ} \mathrm{C}$, concluding that birds submitted to a constant temperature of $35^{\circ} \mathrm{C}$ produced significantly less eggs than those maintained at $24.5^{\circ} \mathrm{C}$.

The percentage of saleable eggs was not different between that produced by quails under thermoneutral temperature and those submitted to cyclic heat stress of $24,27,30$ and $33^{\circ} \mathrm{C}$. However, when birds were submitted to severe cyclic heat stress $\left(36^{\circ} \mathrm{C}\right)$, the percentage of saleable eggs was reduced in $14.33 \%$, possibly due to poor eggshell quality as a result of respiratory alkalosis. When poultry increase their respiratory rate to loose body heat by evaporation, excessive carbon dioxide is lost, with consequent reduction of $\mathrm{CO}_{2}$ and bicarbonate blood levels, compromising the dissociation of $\mathrm{Ca}$ required for eggshell deposition during egg formation.

Table 1 - Feed intake (FI), Egg production (EP), percentage of saleable eggs (SE), egg weight (EW), egg mass (EM), feed conversion ratio per dozen (FCR/dz) and per $\mathrm{kg}(\mathrm{FCR} / \mathrm{kg})$ of egg produced by Japanese quails submitted to cyclic heat stress.

\begin{tabular}{|c|c|c|c|c|c|c|c|}
\hline Temp $\left({ }^{\circ} \mathrm{C}\right)$ & FI (g/bird/day) & EP (\%) & SE (\%) & EW (g) & EM (g/bird/day) & FCR/dz & $\mathrm{FCR} / \mathrm{kg}$ \\
\hline 21 & 30.9 & 83.06 & 80.80 & 12.28 & 10.36 & 0.45 & 2.98 \\
\hline 24 & 30.1 & 83.64 & 81.00 & 12.05 & 10.09 & 0.43 & 3.00 \\
\hline CV $(\%)$ & 4.54 & 4.10 & 4.88 & 2.45 & 4.47 & 5.62 & 6.01 \\
\hline 21 & $28.2 \mathrm{~A}$ & 81.47 & 76.12 & $12.02 \mathrm{~A}$ & 9.79A & $0.42 \mathrm{~A}$ & 2.90 \\
\hline 27 & $26.0 \mathrm{~B}$ & 80.71 & 75.54 & $11.41 \mathrm{~B}$ & $9.20 \mathrm{~B}$ & $0.39 B$ & 2.81 \\
\hline CV (\%) & 4.11 & 4.06 & 5.20 & 1.93 & 3.95 & 5.84 & 5.12 \\
\hline 21 & $28.4 \mathrm{~A}$ & 79.96 & 75.56 & $12.14 \mathrm{~A}$ & $9.71 \mathrm{~A}$ & $0.43 \mathrm{~A}$ & $2.92 \mathrm{~A}$ \\
\hline 30 & $25.0 \mathrm{~B}$ & 79.91 & 75.00 & $11.42 \mathrm{~B}$ & $9.12 \mathrm{~B}$ & $0.38 \mathrm{~B}$ & $2.74 \mathrm{~B}$ \\
\hline CV (\%) & 4.48 & 4.85 & 5.21 & 1.40 & 4.36 & 5.70 & 5.92 \\
\hline 21 & $27.6 \mathrm{~A}$ & 80.76 & 74.97 & $12.03 \mathrm{~A}$ & $9.71 \mathrm{~A}$ & $0.41 \mathrm{~A}$ & 2.84 \\
\hline 33 & $23.0 B$ & 77.25 & 71.21 & 11.19B & $8.64 \mathrm{~B}$ & $0.36 \mathrm{~B}$ & 2.66 \\
\hline CV (\%) & 8.52 & 5.17 & 7.05 & 2.93 & 5.42 & 9.37 & 9.09 \\
\hline 21 & $28.3 A$ & $79.04 \mathrm{~A}$ & $72.84 \mathrm{~A}$ & $12.32 \mathrm{~A}$ & $9.74 \mathrm{~A}$ & $0.43 \mathrm{~A}$ & 2.93 \\
\hline 36 & $22.2 \mathrm{~B}$ & 73.77B & $62.40 \mathrm{~B}$ & $10.85 B$ & $8.01 \mathrm{~B}$ & $0.36 \mathrm{~B}$ & 2.79 \\
\hline CV (\%) & 6.96 & 5.28 & 7.03 & 2.51 & 6.53 & 8.60 & 9.29 \\
\hline
\end{tabular}

A,B - Means followed by different capital letters in the same column within each temperature cycle are different 
The cyclic heat stress of $27^{\circ} \mathrm{C}$ resulted in a significant drop of $5.07 \%$ in egg weight compared with the comfort temperature. When birds were subjected to cyclic heat stress of 30,33 and $36{ }^{\circ} \mathrm{C}$ egg weight was reduced in $5.93 \% ; 6.98 \%$ and $11.93 \%$, respectively. These results may have been caused by the significant reduction in feed intake when the birds were submitted to temperatures of $27^{\circ} \mathrm{C}$ and higher, as the essential nutrients consumed were deviated to maintain homeostasis and therefore were unavailable for egg production. Bordas \& Minvelle (1997) also observed negative effects of heat stress in a study with different strains of layer chickens. When the birds were submitted to environmental temperatures of $21^{\circ} \mathrm{C}$ or $35^{\circ} \mathrm{C}$, the authors observed reductions of $13 \%$ in egg production and of $4 \%$ in egg weight at $35^{\circ} \mathrm{C}$, but no differences were detected among layer strains.

Egg mass (EM) was significantly lower when birds were submitted to heat stress, starting at $27^{\circ} \mathrm{C}$, with $6.37 \%$ reduction as compared with that of birds submitted to thermoneutral temperature. Egg mass reduced in 6.04, 10.93, and $17.78 \%$ when cyclic temperatures of 30,33 and $36^{\circ} \mathrm{C}$ were applied, respectively. This was a result of the lower egg production and egg weight observed at those temperatures. However, Emery et al. (1984) did not report any differences in egg production and in egg mass when the performance and egg quality of 33-weekold layer chickens housed in three climatic chambers (constant temperature of $23.9^{\circ} \mathrm{C}$; cyclic temperature between 15.6 and $37.7^{\circ} \mathrm{C}$ and; cyclic temperature between 21.1 and $37.7^{\circ} \mathrm{C}$ ) were evaluated.

As to feed conversion ratio per dozen eggs, the best results were obtained when birds were exposed to cyclic temperature of $27^{\circ} \mathrm{C}$, because in this group, feed intake was greatly reduced, but there was no proportional decrease in egg production. Significant results in feed conversion ratio per $\mathrm{kg}$ were obtained only when birds were exposed to a temperature of $30{ }^{\circ} \mathrm{C}$, with $6.16 \%$ improvement compared with thermoneutral temperature. However, if birds were exposed to heat stress for longer periods, they would probably need to mobilize their body reserves to supply their maintenance requirements, thereby reducing nutrients available for performance requirement, including egg production.

Egg quality data of Japanese quails submitted to cyclic heat stress are presented in Table 2.

Egg specific gravity was significantly reduced only when birds were submitted to cyclic heat stress of $36{ }^{\circ} \mathrm{C}$ relative to thermoneutral temperature conditions. Molino et al. (2009) asserted that the best way to analyze eggshell quality is to evaluate eggshell breaking strength. In the present study, eggshell breaking strength was significantly reduced $(p<0.05)$ in $9.70 \%$ when the temperature of $24^{\circ} \mathrm{C}$ was applied as compared to $21^{\circ} \mathrm{C}$. At the temperature of $30^{\circ} \mathrm{C}$, eggshell breaking strength was reduced in $13.25 \%$ relative to that obtained under thermoneutral temperature. No significant differences in this parameter between birds submitted to 27 ,

Table 2 - Specific gravity (SG), eggshell breaking strength (BS), eggshell thickness (ET), eggshell percentage $(\mathrm{ESP})$, yolk index $(\mathrm{YI})$, yolk percentage $(\mathrm{YP})$, albumen percentage $(\mathrm{AP})$ and Haugh units $(\mathrm{HU})$ of the eggs produced by Japanese quails submitted to cyclic heat stress.

\begin{tabular}{ccccccccc}
\hline Temp $\left({ }^{\circ} \mathbf{C}\right)$ & $\mathbf{S G}\left(\mathbf{m g} / \mathbf{c m}^{3}\right)$ & $\mathbf{B S}(\mathbf{g})$ & $\mathbf{E T}(\mathbf{m m})$ & ESP $(\%)$ & YI & YP (\%) & AP (\%) & HU \\
\hline 21 & 1.072 & $962.71 \mathrm{~A}$ & 0.21 & 7.76 & 0.47 & 30.06 & 62.17 & 89.29 \\
24 & 1.072 & $869.28 \mathrm{~B}$ & 0.21 & 7.84 & 0.48 & 29.71 & 62.45 & 89.13 \\
\hline $\mathrm{CV}(\%)$ & 0.21 & 8.20 & 2.10 & 3.10 & 2.18 & 1.74 & 0.93 & 2.39 \\
\hline 21 & 1.073 & 886.41 & $0.21 \mathrm{~A}$ & 7.92 & 0.48 & 30.25 & 61.82 & 92.40 \\
27 & 1.073 & 873.37 & $0.20 \mathrm{~B}$ & 7.83 & 0.47 & 29.81 & 62.39 & 88.65 \\
\hline $\mathrm{CV}(\%)$ & 0.21 & 9.13 & 3.88 & 3.14 & 4.18 & 3.18 & 1.52 & 4.86 \\
\hline 21 & 1.075 & $961.06 \mathrm{~A}$ & 0.21 & 8.02 & 0.45 & 30.04 & $61.94 \mathrm{~A}$ & 85.09 \\
\hline 30 & 1.075 & $833.71 \mathrm{~B}$ & 0.21 & 7.82 & 0.45 & 29.09 & $63.24 \mathrm{~B}$ & 86.35 \\
\hline $\mathrm{CV}(\%)$ & 0.16 & 10.07 & 3.06 & 2.74 & 2.72 & 3.51 & 1.81 & 3.50 \\
\hline 21 & 1.073 & 942.49 & $0.21 \mathrm{~A}$ & 8.02 & 0.45 & 30.01 & 61.97 & 87.91 \\
\hline 33 & 1.073 & 966.64 & $0.20 \mathrm{~B}$ & 7.92 & 0.45 & 29.63 & 62.71 & 88.78 \\
\hline $\mathrm{CV}(\%)$ & 0.28 & 11.52 & 4.68 & 3.45 & 3.48 & 4.12 & 1.94 & 2.78 \\
\hline 21 & $1.073 \mathrm{~A}$ & 860.02 & 0.20 & 7.79 & 0.46 & 30.29 & 61.91 & 89.01 \\
\hline 36 & $1.070 \mathrm{~B}$ & 844.65 & 0.19 & 7.79 & 0.45 & 29.86 & 62.34 & 88.63 \\
\hline $\mathrm{CV}(\%)$ & 0.16 & 9.24 & 6.08 & 3.16 & 4.38 & 3.73 & 1.66 & 2.30 \\
\hline $\mathrm{A}$ & & &
\end{tabular}

$A, B$ - Means followed by different capital letters in the same column within each temperature cycle are different by the test of Tukey $(p \leq 0.05)$.
33 or $36^{\circ} \mathrm{C}$ and those maintained at thermoneutral temperature were observed. These results may be related to the high coefficient of variation obtained for this parameter.

Eggshell thickness was significantly reduced in $4.37 \%$ when birds were submitted to cyclic heat stress of $27{ }^{\circ} \mathrm{C}$ compared with thermoneutral temperature. When quails were submitted to $33{ }^{\circ} \mathrm{C}$, eggshell thickness was reduced in $4.33 \%$. No eggshell thickness differences between birds submitted to 30 or $36^{\circ} \mathrm{C}$ and those maintained at thermoneutral temperature were observed. Mashaly et al. (2004) submitted 
31-week-old layer chickens to three treatments in an environmental chamber, with cyclic temperatures and constant heat stress of $35^{\circ} \mathrm{C}$ and $50 \% \mathrm{RH}$, and observed significant reductions in feed intake and weight gain, as well as in egg weight, eggshell thickness and weight, and egg specific gravity in layers submitted to heat stress. These results are consistent with the findings of the present study.

Egg internal quality is evaluated particularly by yolk index and Haugh units. There was no effect of the applied temperatures on these parameters. This suggests that the duration and magnitude of exposure to high environmental temperatures should be taken into account.

Table 2 also shows that yolk and eggshell percentages were not influenced by the thermoneutral temperature or by the tested temperatures. However, albumen percentage was significantly reduced in $2.10 \%$ in the eggs of quails exposed to cyclic heat stress of $30^{\circ} \mathrm{C}$ as compared to the eggs of those maintained under the thermoneutral temperature $\left(21^{\circ} \mathrm{C}\right)$.

\section{CONCLUSIONS}

Under the conditions of the present study, Japanese quails exposed to $27{ }^{\circ} \mathrm{C}$ already presented signs of heat stress, as shown by reduced feed intake and egg weight and mass. The cyclic increase of the environmental temperature to $36^{\circ} \mathrm{C}$ negatively influenced the percentage of saleable eggs and egg production. The effects of cyclic temperatures on egg quality parameters did not allow clear conclusions.

\section{REFERENCES}

Baêta FC. Acondicionamento térmico natural de galpões avícolas.Anais do Simpósio Goiano de Avicultura;1998; Goiânia, Goiás. Brasil. p.29-34.

Bordas A, Minvelle F. Responsé à la chaleur de poules pondeuses issues de lignées sélectionnéss pour une faible $\left(R^{-}\right)$ou forte $\left(R^{+}\right)$consomation alimentaire résiduelle. Genetics, Selection, Evolution 1997; 29(3):279290.

Bottje WG, Harrison PC. The effect of tap water, carbonated water, sodium bicarbonate, and calcium chloride on blood acid-base balance in cockerels subjected to heat stress. Poultry Science 1985; 64(1):107113.

Brant AW, Otte AW, Norris KH. Recommended standards for scoring and measuring opened egg quality. Food Technology 1951; 5:356-361.

Campos EJ. Avicultura: razões fatos e divergências. Belo Horizonte: Editora FEPMVZ; 2000

Emery DA, Vhora R, Ernst RA. The effect of cyclic and constant ambient temperatures on feed consumption, egg production, egg weight, and shell thickness of hens. Poultry Science 1984; 63:2027-2035.
Furlan RL, Macari M, Moraes VMB, Malheiros RD, Malheiros EB, Secato ER. Alterações hematológicas e gasométricas em diferentes linhagens de frangos de corte submetidos ao estresse calórico agudo. Revista Brasileira de Ciência Avícola 1999; 1(1):77-84.

Hannas, MI. Aspectos fisiológicos e a produção de suínos em clima quente. In: Silva IJA, editor. Ambiência e qualidade na produção industrial de suínos. Piracicaba: Fundação de Estudos Agrários Luiz de Queiroz; 1999. p. 01-33.

Jones JE, Hughes BL, Barnett BD. Effect of choching dietary energy levels and environmental temperatures on feed consumption and eggs production of sinle comb white Leghorns. Poultry Science 1976; 55(1):274-277.

Macari M, Furlan RL, Maiorka A. Aspectos fisiológicos e de manejo para manutenção da homeostase térmica e controle de síndromes metabólicas. In: Mendes AA, Nääs IA; Macari, M, editores. Produção de frangos de corte. Campinas: Fundação Apinco de Ciência e Tecnologia Avícolas; 2004. p.137-155

Macari M, Furlan RL, Gonzales E. Fisiologia aviária aplicada a frangos de corte. Jaboticabal: FUNEP/UNESP; 1994.

Mashaly MM, Hendrics GL, Kalama MA, AE Gehad, AO Abbas, PH Patterson. Effect of heat stress on production parameters and imune response of comercial laying hens. Poultry Science 2004; 83:889-894.

Mazzuco H. Bem-estar na avicultura de postura comercial: sob a óptica científica. Avicultura industrial 2006; 1:18-20.

Molino AB, Garcia EA, Gonçalves HC, Pelícia K, Berto DA, Silva AP. Avaliação de medidas de qualidade da casca dos ovos de poedeiras comerciais. Anais do 7. Congresso de Produção, Comercialização e Consumo de Ovos; 2009; São Pedro, São Paulo. Brasil. p.164-167.

Mongin PE. Role of acid-base balance in the physiology of egg-shell formation. World's Poultry Science Journal 1968; 24:200-230.

Murakami AE, Ariki J. Produção de codornas japonesas. Jaboticabal: FUNEP; 1998. 79 p.

Nääs IA. Fatores não nutricionais que afetam desempenho de frangos de corte. Anais da Conferência Apinco de Ciência e Tecnologia Avícolas; 1992; Santos. São Paulo. Brasil. Campinas: Fundação Apinco de Ciência e Tecnologia Avícolas; 1992.

SAS. SAS User's guide: statistics. $5^{\text {th }}$ ed. Cary: SAS Institute; 2000.

Silva IJO. Qualidade do ambiente e instalações na produção industrial de suínos.Anais do 4 Simpósio Internacional de Suinocultura; 1999; São Paulo, SP. Brasil. São Paulo: Gessuli; 1999.p. 108-121.

Silva MAN, Silva IJO, Piedade SMS, Martins E, Coelho AA, Savino VJM Resistência ao estresse calórico em frangos de corte de pescoço pelado. Revista Brasileira de Ciência Avícola 2001; 3(1):27-33.

Tinôco IFF. Estresse calórico e meios naturais de condicionamento.Anais do 1 Simpósio Internacional sobre Ambiência e Instalação na Avicultura Industrial;1995; Campinas, São Paulo. Brasil. Campinas: Facta; 1995. p.99-108.

Yahav S, Shinder D, Tanny J, Cohen S. Sensible heat loss: the broiler's paradox. World's Poultry Science Journal 2005; 61 (3): 419-434.

Yunis R, Cahaner A. The effects of naked neck $(\mathrm{Na})$ and frizzle $(\mathrm{F})$ genes on growth and meat yields of broilers and their interactions with ambient temperatures and potential growth rate. Poultry Science 1999; 78: 1347-1352 